\title{
Kapitał naukowy uczniów jako przedmiot analiz teoretycznych i empirycznych ${ }^{2}$
}

\begin{abstract}
The article is aimed at presenting the category of science capital as a new category in the field of pedagogical research. Science capital as a construct was proposed in the second decade of the 21st century by the team of Louise Archer from King's College. This category consists of: (1) scientific forms of cultural capital, (2) behavior and practices related to science, and (3) scientific forms of social capital. The text presents the development of this concept together with a discussion of its elements and their meaning. Scientific capital can be one of the greatest wealth of society, and its use depends on the future development of not only individual units, but also the country and the possibility of high achievements in the fields of science. This is a very current issue, therefore it is important to better understand the shaping of the science capital of young people. The text also reviews the previous empirical studies devoted to the analyzed category. On this basis, it was concluded that scientific capital as an educational variable is still subjected to reconceptualization, requires refinement and further exploration.
\end{abstract}

1 Aleksandra Tłuściak-Deliowska, Katedra Dydaktyki, Wydział Nauk Pedagogicznych, Akademia Pedagogiki Specjalnej im. Marii Grzegorzewskiej w Warszawie, Polska. adeliowska@aps.edu.pl.

2 Artykuł przygotowano w ramach realizacji projektu BSTP 7/17- I WNP APS „Kapitał naukowy polskich uczniów - identyfikacja i uwarunkowania. Badania pilotażowe”. 


\section{Keywords:}

cultural capital, social capital, science capital, science, education, science aspiration

\section{WPROWADZENIE: NAUKA I JEJ ZNACZENIE DLA INNOWACYJNEJ GOSPODARKI}

Nauka (science) staje się coraz cenniejszym zasobem na całym świecie (por. Aschenbacher i in., 2010, s. 564), zaś zawody związane ze STEM (Science, Technology, Engineering, Mathematics) są i prawdopodobnie pozostaną najważniejsze z punktu widzenia rozwoju cywilizacyjnego i gospodarczego kraju. Z tego też względu, coraz bardziej uwaga skupiona jest na potencjale intelektualnym społeczeństwa, od którego zależy jego rozwój oraz możliwość wysokich osiągnięć w dziedzinach nauki. Tymczasem, jak zauważył Piwowarski (2017) na podstawie wielu badań prowadzonych także w Polsce, wiadomo, że zbyt mała liczba młodych ludzi wybiera studia i zawody związane z tymi dyscyplinami. Ten stan rzeczy w przyszłości może doprowadzić do zahamowania rozwoju społeczno-gospodarczego kraju, zaś z punktu widzenia jednostki do bezrobocia wynikającego z niedopasowania wykształcenia do oczekiwań rynku pracy. Dlatego też w ostatnim czasie podejmowane są różnego rodzaju działania w zakresie polityki edukacyjnej mające na celu m.in. zachęcenie młodych ludzi do wyboru takiej drogi zawodowej (np. kampania Dziewczyny na politechniki! i Dziewczyny do ścisłych! jako największy projekt promujący kierunki techniczne, inżynierskie i ścisłe wśród młodych kobiet w Polsce i w Europie Środkowo-Wschodniej) w celu zwiększenia konkurencyjności na rynku pracy, wzmocnienia innowacyjności, ale także w szerszej perspektywie - rozwoju nauki i technologii w kraju.

Systemy edukacyjne i szkoły odgrywają kluczową rolę w określaniu zainteresowań dzieci i młodzieży przedmiotami STEM, a także w zapewnianiu równych szans dostępu do wysokiej jakości edukacji i czerpania z niej odpowiednich korzyści. Nauka przedmiotów ścisłych w szkole średniej jest niezbędna do podejmowania studiów w zakresie przedmiotów ścisłych, a studiowanie przedmiotów ścisłych jest zazwyczaj niezbędne do kariery zawodowej w tym obszarze. W związku z tym, odpowiednie doświadczenia szkolne mogą być szczególnie ważne w ułatwianiu lub wykluczaniu przyszłej kariery naukowej (por. Claussen, Osborne, 2013).

W celu podejmowania jakichkolwiek działań mających na celu zmianę sytuacji na rynku pracy i tym samym sytuacji gospodarczej kraju, niezbędne jest prowadzenie badań naukowych, które pozwolą zrozumieć proces kształtowania aspiracji 
i zaangażowania młodych ludzi w naukę. Wychodzi temu naprzeciw kategoria kapitału naukowego (ang. science capital), która jest przedmiotem niniejszego tekstu. Artykuł ma charakter przeglądowy i ma na celu przybliżenie kategorii kapitału naukowego uczniów, jego elementów składowych oraz dotychczasowych sposobów jego badania. W tekście skoncentrowano się na badaniach ujmujących analizowaną kategorię wprost. Szereg bowiem jego elementów czy powiązanych z nim zagadnień jest przedmiotem wielu innych studiów teoretycznych i empirycznych, których nie sposób omówić w jednym tekście.

\section{KATEGORIA KAPITAŁU NAUKOWEGO JAKO PRZEDMIOT ANALIZ TEORETYCZNYCH}

Kategoria kapitału naukowego jest na gruncie badań pedagogicznych pojęciem nowym. Zaproponował je w drugiej dekadzie XXI wieku zespół Louise Archer z King’s College, szukający przyczyn istotnych różnic pomiędzy wyborami drogi zawodowej uczniów z tych samych szkół (Archer i in., 2013). Koncepcja ta została rozwinięta w kontekście badań dotyczących aspiracji młodych ludzi prowadzonych w ramach projektu ASPIRES. Badacze szybko dostrzegli, że dotychczas istniejące kategorie socjokulturowe są niewystarczające, by zrozumieć mechanizmy dokonywania wyboru drogi zawodowej przez absolwentów. Koncepcja zaproponowana przez Archer i jej zespół miała przyczynić się do zrozumienia, jak aspiracje młodych ludzi zmieniają się w czasie (jak się kształtują), w szczególności te dotyczące wyboru kariery zawodowej związanej z nauką (science-related career).

Pojęcie kapitału naukowego zostało przez Archer i współpracowników wywiedzione z Bourdieu’owskiej konceptualizacji „kapitału”, zgodnie z którą kapitał rozumiany jest jako zasoby ekonomiczne, kulturowe i społeczne, z których mogą korzystać osoby je posiadające, w celu uzyskania przewagi w określonych kontekstach społecznych. Według Bourdieu kapitał wchodzi w interakcję z habitusem (wewnętrzną matrycą dyspozycji osoby, która jest kształtowana w efekcie socjalizacji). Niektórzy badacze porównują kapitał do różnych rodzajów umiejętności i zasobów, podobnych do „kart” (i znajomości „reguł”), które gracz może posiadać w określonej „grze”. Karty te określają jego zdolność do gry i szansę na „wygraną”/ „przegraną” w konkretnej „grze” (Lareau, Horvat, 1999).

Piwowarski (2017) stwierdził, że kapitał naukowy może być ujmowany na kilka sposobów. Po pierwsze, jako część składowa kapitału kulturowego. Po drugie, jako całkowicie autonomiczny czynnik. Po trzecie, jako wypadkowa kapitału kulturowego, społecznego i ekonomicznego. Po czwarte, jako „naukowe” formy 
kapitału kulturowego i społecznego, „które decydują o wysokiej jakości symbolicznej i wymiennej kapitału” (Piwowarski, 2017, s. 142). Trzecie rozumienie jest podejmowane najczęściej i jest tożsame z podejściem zaproponowanym przez Archer. W związku z tym, że koncepcja kapitału została rozwinięta właśnie przez zespół tej badaczki i to do niej większość prac aktualnie się odnosi (chodzi zarówno o prace kontynuujące wywód Archer, jak i dyskutujące z nią), tej koncepcji poświęcono w niniejszym tekście najwięcej miejsca.

Kapitał naukowy początkowo został przez zespół Archer zdefiniowany jako powiązane z nauką kwalifikacje, zrozumienie i wiedza (dotycząca nauki, jej funkcjonowania) oraz zainteresowania i kontakty społeczne, z których może wynikać lepsza orientacja w problematyce naukowej (np. znajomość z kimś, kto pracuje w zawodzie związanym z nauką) (Archer i in., 2013). Tak rozumiany kapitał miał być narzędziem koncepcyjnym, za pomocą którego można wyjaśnić produkcję klasowych wzorów formowania aspiracji naukowych dzieci i młodzieży. Przy jednoczesnym założeniu, że ów kapitał nie stanowi odrębnego rodzaju kapitału, lecz jest raczej kombinacją tych elementów kapitału społecznego, kulturowego i ekonomicznego, które w szczególności odnoszą się do nauki i które mogą budować naukowy potencjał, a więc przyczyniać się do wspierania i zwiększania osiągnięć, zaangażowania lub/i uczestnictwa w nauce (Archer i in., 2013, s. 5).

Konceptualizacja kapitału naukowego była (i jest) przez zespół Archer w dalszym ciągu rozwijana i doprecyzowywana w kolejnych latach, by wyjaśnić wzajemne relacje pomiędzy poszczególnymi elementami budującymi ów kapitał. Tych elementów aktualnie Archer i współpracownicy (2015) wyróżniają osiem. Pierwszą grupę tworzą trzy elementy kapitału kulturowego związane z nauką (naukowe formy kapitału kulturowego), tj.: (1) alfabetyzm naukowy (konceptualizowany jako wiedza naukowa, umiejętności i rozumienie, jak „działa” nauka oraz zdolność jej w życiu codziennym dla korzyści osobistych i społecznych), (2) dyspozycje/ preferencje naukowe oraz (3) symboliczna wiedza na temat możliwości przełożenia nauki na rynek pracy (np. możliwość przenoszenia kwalifikacji naukowych). Drugą grupę tworzą zachowania i praktyki związane z nauką, takie jak: (1) konsumpcja mediów związanych z nauką oraz (2) uczestniczenie w pozaszkolnych formach organizacyjnych kształcenia związanych z nauką (np. zwiedzanie muzeów, centrów nauki, itp.). Trzecią grupę tworzą elementy kapitału społecznego związane z nauką (naukowe formy kapitału społecznego), tj.: (1) wiedza naukowa i kwalifikacje rodziców/członków rodziny, (2) znajomość z osobami, które wykonują zawody związane z nauką oraz (3) rozmowy z innymi (poza szkołą) w życiu codziennym o nauce (zob. także King i in., 2015). Choć te elementy zostały wymienione oddzielnie, co jest podyktowane głównie potrzebą przejrzystej ich prezentacji, 
autorzy koncepcji kapitału naukowego traktują je jako przenikające się wymiary kapitału i wchodzące ze sobą w liczne interakcje.

Pierwotna koncepcja kapitału naukowego zaproponowana przez Archer stała się dość szybko przedmiotem dyskusji i krytyki. Jensen i Wright (2015, s. 1143) stwierdzili, że dokonana przez Archer konceptualizacja kapitału naukowego prowadzi do zawężenia horyzontu analiz i może skutkować ciągłym wyróżnianiem na podobnej zasadzie kolejnych kategorii kapitału, np. kapitał sportowy, matematyczny itd., co spowoduje niepotrzebne rozdrobnienie przedmiotu badań. Dlatego też proponują, stosowanie określenia „kapitał kulturowy w science education" (2015, s.1143) i postulują, by w miejsce wąskiego skupiania się na nauce jako specjalnym przypadku, spojrzeć z szerszej perspektywy i zobaczyć, że nauka jest z jednym z elementów większego niesprawiedliwego systemu społeczno-kulturowego (2015, s.1146).

Problem ten został podjęty także przez indyjskich badaczy Kumar i Singhb (2017), którzy stwierdzili, że koncepcja kapitału naukowego w niewystarczającym stopniu koncentruje się na praktykach i zachowaniach związanych z nauką w społeczeństwie opartym na wiedzy. Zdaniem tych badaczy koncepcja Archer bazuje na wąskim rozumieniu nauki, przyczynia się do wzmacniania „psychozy rynkowej” i prowadzi do nadmiernego uproszczenia w odniesieniu do przenoszenia kapitału związanego z nauką z jednego pokolenia na następne. Uwypukla bowiem czynniki różnicujące o charakterze społeczno-kulturowym, a przede wszystkim te związane z pochodzeniem jednostki. Przyjęcie kategorii kapitału naukowego w rozumieniu Archer w pewnym sensie podważa traktowanie jednostki jako autonomicznej i samorefleksyjnej. Tymczasem zdaniem Kumar i Singhb te właściwości są kluczowe dla zrozumienia tego, kim jest uczący się i do czego dąży (s. 73). Inwestowanie w edukację przyczynia się zaś do tego, że uczniowie, mając wiedzę i jej świadomość, mogą ją wykorzystać do zanegowania determinizmu społecznego i zmiany swojej sytuacji życiowej. W związku z tym proponują nową koncepcję teoretyczną nazwaną „polem nauki” (Science Field) jako uzupełnienie kategorii kapitału naukowego. Ich zdaniem stwarza ona możliwość zmierzenia niuansów nieuwzględnionych powyżej, czyli indywidualnych koncepcji ucznia i zdobywania wiedzy o nauce, o metodach naukowych, ich habitusie, dyspozycjach naukowych i preferencjach, zachowaniach i praktykach związanych z nauką oraz ich przydatności do stosowania wiedzy naukowej w życiu osobistym i społecznym. Koncepcja ta ujmuje jednostkę z jednej strony jako istotę niezależną ze swoją autonomiczną przestrzenią, ale z drugiej - zależną i funkcjonującą w złożonym społeczeństwie. Autorom zależy na podkreśleniu, że jednostka ma możliwość wpływu na swoje życie i zmiany, a nie tylko reprodukcji społeczno-kulturowej. Z pedagogicznego 
punktu widzenia, to uzupełnienie zdaje się być znaczące i aktualne, bowiem zakłada się, że to właśnie edukacja stwarza możliwość niwelowania nierówności społecznych, wyrównywania szans dzieci z grup wykluczonych społecznie lub zagrożonych takim wykluczeniem. Zyskuje to potwierdzenie, gdy przywołamy chociażby eksplorowaną także w ostatnim czasie kategorię academic resilience (pomijając rozważania dotyczące terminologii), która odnosi się do swoistej odporności uczniów, którzy pomimo tego, że pochodzą ze środowisk dewaforyzowanych, wykazują wysoki poziom osiągnięć szkolnych, a zatem przezwyciężają statusową determinację (por. Smulczyk, 2016).

\section{KAPITAŁ NAUKOWY JAKO PRZEDMIOT BADAŃ WYRAŻONY EXPLICITE}

Przegląd badań poświęconych kapitałowi naukowemu uczniów należy rozpocząć od przywołania badań podejmowanych przez zespół Louise Archer, które prowadzone są w sposób systematyczny i które przyczyniły się do wzrostu zainteresowania tą kategorią. Pierwsze badania były realizowane w ramach projektu ASPIRES (Archer i in., 2013). Program trwał pięć lat i był finansowany przez Brytyjską Radę ds. Badań Gospodarczych i Społecznych (UK’s Economic and Social Research Counsil; ESRC). Procedura badawcza obejmowała przeprowadzenie ankiet online realizowanych w kohorcie uczniów (badania ilościowe) i powtarzanych wywiadów w wybranych podgrupach uczniów i ich rodziców (badania jakościowe). Badania ankietowe i wywiady realizowane były trzykrotnie: pod koniec szkoły podstawowej (10/11 lat, klasa 6), w drugim roku szkoły średniej (12/13 lat, klasa 8) oraz w trzecim roku szkoły średniej (13/14 lat, klasa 9). W sumie zebrano 19 tys. ankiet (9319 od uczniów z klasy 6; 5634 od uczniów z klasy 8; 4600 od uczniów z klasy 9). Grupa 83 uczniów oraz 65 ich rodziców wzięła udział w wywiadach. Na zakończenie realizacji projektu podjęto współpracę z grupą nauczycieli z Londynu, którzy przygotowali programy lekcji uwzględniając wyniki projektu. Kapitał naukowy w tych badaniach został zoperacjonalizowany jako konstrukt składający się z czterech wymiarów: (1) umiejętność korzystania z nauki (wiedza naukowa i rozumienie); (2) postawy i wartości związane z nauką (m.in. dostrzeganie roli nauki w życiu codziennym), (3) pozaszkolne zachowania związane z nauką (m.in.: znajomość czasopism naukowych, oglądanie naukowych programów telewizyjnych, chodzenie do muzeów, centrów naukowych itp.); (4) nauka (science) w domu (np. kwalifikacje naukowe członków rodziny, znajomość osób ze środowiska rodzinnego zajmujących się nauką itp.). Ankieta, którą wypełniali uczniowie, zawierała pytania dotyczące wyżej wskazanych obszarów oraz pytania dotyczące danych 
demograficznych. W większości pytań zastosowano skalę odpowiedzi Likerta. Analiza zgromadzonego materiału badawczego wykazała, że większość młodych ludzi w wieku 10-14 lat ma stosunkowo wysokie aspiracje związane z karierą zawodową, głównie techniczną i menadżerską. Prawie wszyscy uczniowie i ich rodzice cenili edukację. Około 15\% badanych uczniów aspirowało do bycia naukowcem. Ten rodzaj aspiracji był reprezentowany jednak w najmniejszym stopniu. Znacznie bardziej popularne były inne zawody związane ze STEM, takie jak np. medycyna. Większość uczniów (60\%) wiązała jednak swoją przyszłość z biznesem. Zidentyfikowane aspiracje pozostawały na relatywnie stałym poziomie od 10 do 14 roku życia (gdy analizowano w obrębie kategorii: nauka, związane ze STEM, niezwiązane ze STEM). Uczniowie, którzy wyrażali najbardziej pozytywne postawy wobec nauki szkolnej, także w największym stopniu aspirowali do zostania naukowcem w przyszłości. Jednak te postawy nie wyjaśniały w całości aspiracji naukowych uczniów. Analiza danych pokazała również, że 42\% uczniów z klas 9. jest zainteresowana nauką w przyszłości. Badani także w pozytywny sposób postrzegali naukowców i wyrażali przekonanie, że ich rodzice cenią sobie naukę. Uwzględnienie w badaniu zaplecza rodzinnego pozwoliło ustalić badaczom decydującą rolę tego czynnika w kształtowaniu aspiracji zawodowych uczniów. Ten wpływ wyraża się na wiele sposobów, ale kluczową kategorią, zdaniem badaczy, jest kapitał naukowy, jaki posiada dana rodzina. Uczniowie, którzy wywodzili się z rodzin ze średnim i wysokim kapitałem naukowym znacznie częściej niż pozostali wskazywali na aspiracje związane z nauką czy zawodami związanymi ze STEM. Dla takiego wyboru zawodu w przyszłości znaczenie miało także skojarzenie osoby naukowca z przekonaniem, że jest to osoba „łebska” (brainy). 80\% badanych uczniów zgodziło się z takim stwierdzeniem. Jednakże ci uczniowie, którzy nie postrzegali siebie w takich kategoriach (nie postrzegali siebie jako jednej z najbystrzejszych osób w klasie), nie planowali wiązać się z nauką w przyszłości. Okazało się, że kapitał naukowy pozostaje w związku z kapitałem kulturowym - wyższy poziom kapitału kulturowego odpowiada za wyższy poziom kapitału naukowego. Na podstawie badań ASPIRES stwierdzono, że największe prawdopodobieństwo naukowych aspiracji było wówczas, gdy badany był płci męskiej, był pochodzenia Azjatyckiego, miał wysoki/bardzo wysoki poziom kapitału kulturowego oraz miał członków rodziny, którzy pracowali w nauce lub innych zawodach związanych ze STEM. Badacze podkreślili, że płeć miała istotne znaczenie dla poszczególnych wyników. Dziewczęta znacznie rzadziej niż chłopcy aspirowały do kariery naukowej, nawet pomimo tego, że większy odsetek dziewcząt niż chłopców wskazywał na przedmioty ścisłe jako ulubione przedmioty szkolne. Dziewczęta raczej wybierały zawody związane ze sztuką i opieką nad innymi (Archer i in., 2013). 
W Kings College w kontekście zainteresowania kapitałem naukowym w latach 2013-2017 zrealizowano kolejny projekt we współpracy z Muzeum Nauki (Londyn) pod nazwą Enterprising Science (Archer i in., 2015; King i in., 2015). Projekt ten skierowany był do uczniów szkoły średniej w wieku 11-16 lat, ich nauczycieli i rodziców. Celem projektu było zwiększenie świadomości na temat użyteczności nauki, a co za tym idzie, zaangażowania młodych ludzi w tą sferę. Badania realizowane w ramach tego projektu stworzyły także możliwość udoskonalenia koncepcji kapitału naukowego poprzez dokładną jego operacjonalizację, opracowanie indeksu kapitału naukowego i przygotowanie odpowiedniego narzędzia pomiarowego. W wymiarze praktycznym, celem projektu było wypracowanie strategii, za pomocą których ów kapitał można pielęgnować. Badacze wyszli z założenia, że teoretycznie i praktycznie rozwinięta oraz dopracowana koncepcja kapitału naukowego będzie przydatna zarówno badaczom do dalszych eksploracji naukowych, ale także praktykom, np. nauczycielom przedmiotów ścisłych.

W badaniach udział wzięło 3658 uczniów. Elementy kapitału naukowego zostały zoperacjonalizowane w trzy grupy, opisane we wcześniejszej części tego artykułu, tj.: (1) naukowe formy kapitału kulturowego, (2) zachowania i praktyki związane z nauką oraz (3) naukowe formy kapitału społecznego. Do każdego elementu zaproponowano różne itemy, w efekcie czego otrzymano kwestionariusz poddany dalszym analizom psychometrycznym. Na podstawie zgromadzonych danych udało się opracować indeks kapitału naukowego, który można obliczyć dla każdego ucznia. Odpowiedzi uczniów w ankiecie były odpowiednio punktowane i zsumowane. Wartość kapitału naukowego mieściła się w przedziale od 0 do 105 punktów, ze średnią 43,65 i odchyleniem standardowym 15,45. Bazując na rozkładzie odpowiedzi, wyróżniono trzy poziomy kapitału naukowego: (1) niski (0-34 pkt), (2) średni (35-69 pkt) oraz (3) wysoki (10-105 pkt). W badanej grupie uczniów ów rozkład przedstawiał się następująco: wysokim poziomem kapitału charakteryzowało się $5 \%$ badanych, średni poziom charakterystyczny był dla $68 \%$, a pozostałe $27 \%$ uczniów miało kapitał naukowy określony jako niski. Wysoki kapitał naukowy charakterystyczny był dla uczniów, którzy przejawiają wysoką alfabetyzację naukową i mają dostęp do wielu źródeł, zarówno kulturowych, jak i społecznych, związanych z nauką. Ci uczniowie są pewni swoich naukowych umiejętności i są też w takich kategoriach postrzegani przez innych. Podejmują przy tym wiele różnych aktywności związanych z nauką, a członkowie ich rodziny (przede wszystkim rodzice) wykonują zawody „naukowe”. W przeciwieństwie do tej grupy, uczniowie o niskim poziomie kapitału naukowego, nie są zainteresowani nauką, są mniej pewni swoim umiejętności, mniej angażują się (albo wcale) w pozaszkolne aktywności sprzyjające uczeniu się i raczej nie mają w rodzinie, ani 
w najbliższym otoczeniu społecznych osób związanych z nauką. Zróżnicowanie poziomu kapitału naukowego z puntu widzenia danych socjodemograficznych było podobne jak w badaniach wcześniejszych. Przede wszystkim, chłopcy uzyskali wyższe wyniki w zakresie kapitału naukowego niż dziewczęta oraz uczniowie pochodzący z Azji Południowej mieli wyższe wyniki w zakresie kapitału naukowego w porównaniu z uczniami białymi i pochodzenia afrykańskiego.

W ramach realizacji projektu Enterprising Science realizowano także partnerski program doskonalenia zawodowego nauczycieli (The Teacher Professional Partnership Programme (TP3); King i in., 2015). I choć z nazwy programu można wnioskować, że chodziło w nim o podniesienie kompetencji, to celem nie było uzupełnienie wiedzy czy umiejętności nauczycieli, lecz wykorzystanie ich wiedzy oraz doświadczenia w zakresie wdrażania praktyk związanych z nauką i reagowania na potrzeby uczniów. Uwzględnienie elementu partnerstwa zaś zakładało wspólne podejście do przedmiotu badań. W ramach realizacji programu wprowadzono wpierw nauczycieli w charakter i znaczenie kapitału naukowego, a następnie wspierano ich w opracowywaniu sposobów wdrażania pedagogiki budowania kapitału naukowego w praktyce. Nie udało się jednak osiągnąć wielu z zakładanych celów. Badacze uzasadniali to niezdolnością nauczycieli do zgromadzenia potrzebnych danych, co było dodatkowo ograniczone przez różnego rodzaju naciski wewnątrzszkolne, w efekcie czego nauczyciele nie mogli się w pełni zaangażować (por. King i in., 2015). W efekcie realizacji programu zgromadzono jednak różnego rodzaju dane pochodzące z wywiadów z uczestniczącymi nauczycielami $(n=10)$, obserwacji praktyk w klasie i analizy relacji nauczycieli z ich praktyki. Wyniki sugerują, że nauczyciele uznali koncepcję kapitału naukowego za atrakcyjną i rezonującą z ich intuicją i doświadczeniem. Jednak sposoby, w jakie koncepcja była operacjonalizowana pod względem wdrażania praktyk pedagogicznych, były różne. Badacze doszli do wniosku, że warto w przygotowaniu nauczycieli poświęcać więcej uwagi kapitałowi naukowemu. Już przez sam fakt jego wyartykułowania może on stać się stałym elementem codziennego słownictwa, a przy tym użytecznym wspólnym mianownikiem do dzielenia się swoimi wrażeniami i przemyśleniami z innymi nauczycielami, w kontekście różnych działań mających na celu zwiększenie kapitału naukowego uczniów.

Badania kapitału naukowego realizowane przez zespół Archer stały się inspiracją do wielu kolejnych badań. W Polsce badania kapitału naukowego przeprowadziło Centrum Nauki Kopernik w Warszawie i to one zostaną teraz omówione, ponieważ bazowano w nich na metodologii zespołu Archer. Najpierw w 2015 r., podczas Pikniku Naukowego, badacze z Centrum Nauki Kopernik przy współpracy Centrum Badania Opinii Społecznej przeprowadzili sondaż wśród obecnych tam 
uczniów (Kapitał naukowy młodzieży 10-19 lat. Raport z badania uczestników XIX Pikniku Naukowego, Warszawa 2015). Na pytanie, jak postrzegają swoje zdolności, 47\% badanych odpowiedziało, że ma umysł ścisły, 27\% uczniów określiło się jako artystyczne dusze, a $22 \%$ powiedziało o sobie, że są humanistami. Spośród tych ostatnich, tylko co dwudziesty uczeń uznał, że mógłby zostać dobrym naukowcem, zaś spośród tych, którzy deklarowali się jako umysły ścisłe - co piąty (por. Iłowiecka-Tańska, 2016). Centrum Nauki Kopernik zrealizowało kolejny, większy, projekt badawczy poświęcony kapitałowi naukowemu w kontekście zwiedzania centrum przez szóstoklasistów (Raport „Wystawy dla Wszystkich”, 2017). Główne pytanie badawcze dotyczyło zakładanej relacji między wartością i strukturą kapitału kulturowego uczniów i jego szczególnej formy, tj. kapitału naukowego a jakością aktywności i doświadczeń poznawczych na wystawach i w interakcji z eksponatami. Badania przeprowadzono w 2016 roku z udziałem ogólnopolskiej, reprezentatywnej grupy szóstoklasistów (N=1231). Przeprowadzono także badania wśród uczniów odwiedzających Centrum Nauki Kopernik. Przyjęto ustalenia, zgodnie z którymi skala kapitału naukowego została wyznaczona przez najniższy i najwyższy wynik uzyskany przez uczniów w badaniu reprezentatywnym. Do utworzenia indeksu kapitału naukowego wykorzystano 25 pytań. Wybrano je z całości kierując się typologią Bourdieu, a zatem odpowiedziami, które dotyczyły zasobów: (1) ucieleśnionych, a więc określonym typem i poziomem kompetencji kulturowej - deklarowanym postrzeganiem znaczenia i zastosowania nauki, (2) uprzedmiotowionych, a więc posiadanymi przez uczniów dobrami kulturowymi, których nabycie i użycie wymaga zresztą także odpowiedniej kompetencji (książki) oraz (3) zinstytucjonalizowanymi, a więc odpowiednimi świadectwami (oceny szkolne). Odpowiedzi uczniów zostały odpowiednio zakodowane i zsumowane. W ten sposób powstał indeks przyjmujący wartości od 0 do 111 . W badaniu na ogólnopolskiej, reprezentatywnej próbie szóstoklasistów żaden z uczniów nie osiągnął maksymalnej punktacji. Najwyższa wartość kapitału to 92 punkty, najniższa - 15. W dalszej kolejności zrekodowano indeks do czterech kategorii kapitału określonych jako: (1) kapitał znikomy (15-33 pkt), (2) kapitał niski (34-52 pkt), (3) kapitał obiecujący (53-72 pkt) oraz (4) kapitał wysoki (powyżej 73 punktów). Przy kategoryzowaniu zastosowano zasadę równego podziału realnej punktacji (czyli od 15 do 92 punktów). Zgodnie z uzyskanymi wynikami okazało się, że 64\% badanych uczniów ma bardzo niski lub niski kapitał naukowy. Niewiele ponad 3\% badanych uczniów charakteryzowało się wysokim poziomem kapitału naukowego. Analizy podjęte podczas opracowywania danych z badania ogólnopolskiego wykazały średni związek między średnią kapitału naukowego dzieci z badanych szkół a wskaźnikiem Edukacyjnej Wartości Dodanej (EWD) 
danej szkoły. Jak wynika z danych, w największym stopniu wykorzystywane są zasoby ulokowane w przestrzeni domu i szkoły. Towarzyszą im przekonania (badacze lokują je w typologii zasobów ucieleśnionych) na temat utylitarnej wartości wiedzy naukowej, przekazywane w środowisku szkolno-domowym. Badani uczniowie wiedzą zatem, że warto się uczyć przedmiotów z obszaru science (nauk ścisłych i przyrodniczych), deklarują wiedzę dotyczącą praktycznego znaczenia nauki, oglądają w telewizji programy naukowe i deklarują, że edukacja sprawia im sporą przyjemność. Badania te pokazują również, że wśród uczniów z najniższym kapitałem naukowym notowany jest najwyższy odsetek wybierających zawody całkowicie niezwiązane z science (71,0\%). Jest on dwukrotnie wyższy niż w grupie osób o wysokim kapitale (36,1\%), w której prawie połowa wymieniła zawody pośrednio lub bezpośrednio związane z science (44,7\%). Badaczom nie udało się jednak potwierdzić hipotezy dotyczącej relacji pomiędzy wartością posiadanego kapitału naukowego a sposobem zwiedzania centrów nauki i interakcją z eksponatami. W tym obszarze wymagane są dalsze badania.

Inny przykład ujęcia kapitału naukowego uczniów stanowią badania Padwick i współpracowników (2016). Prowadzenie badań ilościowych z udziałem uczniów pozwala zdiagnozować poziom kapitału naukowego i formułować na tej podstawie pewne generalizacje. Jednakże tego typu strategia w odniesieniu do uczniów młodszych ma ograniczone zastosowanie. Z tego też względu dobrym rozwiązaniem jest połączenie w jednym badaniu strategii ilościowej i jakościowej z odpowiednim doborem technik badawczych do wieku badanych. W opisywanym badaniu udział wzięło 450 uczniów z północnej Anglii w wieku 7-8 lat (3 klasa) oraz 9-10 lat (5 klasa). Procedura badawcza zawierała następujące techniki: (1) kwestionariusz dotyczący środowiska rodzinnego i zainteresowania nauką (dostosowano i uproszczono pytania z projektu ASPIRES); (2) technikę rangowania elementów (Diamond Ranking: Most like/Most Like a Scientist) oraz (3) technikę sortowania (Sorting Activity: STEM Jobs). Rangowanie polegało na tym, że dzieciom przedstawiono dziewięć kart z napisami dotyczącymi cech charakteru: sprytny, fajny, kreatywny, uprzejmy, przyjazny, zabawny, pracowity, rozsądny, dziwny. Najpierw badani układali karty na kształt diamentu z założeniem, że na samej górze znajduje się cecha odpowiadająca badanemu, czyli „całkiem jak ja” (most like me), na samym dole zaś „zupełnie nie jak ja” (least like me). Następnie badani układali te same karty, ale odnosząc się do założenia „całkiem jak naukowiec” vs „zupełnie nie jak naukowiec”. Z kolei technika sortowania polegała na tym, że badanych wyposażono w 30 kart z różnymi zawodami, które były odczytywane, ale nie wyjaśniano ich znaczenia. Zadanie uczniów polegało na posortowaniu tych zawodów na te, które są im znane i te, których nie znają. Następnie koncentrowano 
się tylko na grupie zawodów znanych dziecku i tym razem zadanie polegało na podzieleniu ich na trzy grupy: chciałbym wykonywać, nie chciałbym, nie jestem pewien. Do analiz wykorzystano dane zgromadzone w grupie 350 dzieci. Okazało się, że dzieci, niezależnie od wieku, płci i poziomu kapitału naukowego, w podobny sposób postrzegają naukowców przypisując im takie właściwości, jak pracowitość, bystrość czy kreatywność. Nie przypisywano im jednak „dziwności”, co stanowi powszechnie powtarzaną zawartość treściową stereotypu naukowca. Ciekawy rezultat dotyczył samoidentyfikacji z poszczególnymi cechami tych dzieci, które miały najwyższy poziom kapitału naukowego. W ich przypadku postrzeganie siebie było zbliżone do postrzegania naukowca. Samoidentyfikacja (samopercepcja) dzieci była jednak przede wszystkim zróżnicowana z punktu widzenia płci. Chłopcy w większym stopniu identyfikowali się z takimi cechami, jak „fajny” i „bystry”, z kolei dziewczęta najczęściej określały siebie jako „pracowite” i ,uprzejme” i raczej nie identyfikowały się też z nauką. Na tej podstawie badaczki stwierdziły, że należy podejmować działania mające na celu zmianę tego stanu rzeczy - zmniejszenie luki między dziewczęcymi samopercepcjami a postrzeganiem naukowców w taki sposób, by postrzegały one STEM jako obszar oferujący karierę dla kogoś takiego ,jak one”.

Jak już wcześniej zaznaczono, zainteresowanie kapitałem naukowym rozwinęło się kontekście wyboru dróg zawodowych młodych ludzi. W wyżej przytoczonych badaniach udział brali zazwyczaj uczniowie (i osoby z ich sieci społecznych), zaś celem była przede wszystkim diagnoza kapitału naukowego i wyjaśnienie aspiracji naukowych. Z nieco innej perspektywy badania przeprowadzili Black i Hernandez-Martinez (2016). Interesowała ich rola kapitału naukowego w pośredniczeniu między pochodzeniem a wyborem studiów związanych ze STEM, jak również kwestia współdziałania kapitału naukowego studentów z ich identyfikacją z przedmiotami STEM na studiach. Nawiązując do badań Archer i współpracowników (2015) zwrócili oni uwagę, że kapitał naukowy jest definiowany przez pryzmat wartości wymiennej i wartości użytkowej, która wspiera indywidualne uczestnictwo i zaangażowanie w przedmioty STEM. Punktem wyjścia do ich badań był także wniosek z projektu ASPIRES, zgodnie z którym, choć wielu studentów postrzega naukę jako potencjalnie użyteczną do przyszłej pracy, znacznie mniej osób uważa, że takie miejsca pracy są osobiście istotne lub możliwe do osiągnięcia przez nich samych (Archer i in., 2013). Badacze sięgnęli po kategorię utożsamienia ze STEM, ale rozumianą nieco inaczej, niż w przypadku badań Archer, bowiem w nich owa tożsamość wynikała z przekonania, że „ktoś postrzega mnie jako osobę naukową”. I choć postrzeganie przez innych jest ważnym elementem kształtowania tożsamości jednostki, to dla tych badaczy bardziej znaczący był czynnik indywidualny i prze- 
łożenie tej tożsamości na działania praktyczne jednostki. Badania przeprowadzono w ramach projektu Transmaths (programy studiów wymagające matematyki), który obejmował wywiady z 50 studentami na trzech etapach studiów: (1) na początku pierwszego roku, (2) pod koniec pierwszego roku i (3) na drugim roku. W wywiadach przyjęto podejście narracyjne, biograficzne, a rozpoczynało je pytanie: powiedz mi, jak doszło do tego, że jesteś studentem na tym kierunku? Następnie dopytywano o kwestie dotyczące poszczególnych elementów kapitału naukowego. Na podstawie analizy wywiadów badacze doszli do wniosku, że koncepcję kapitału naukowego zaproponowaną przez Archer i jej zespół należy nieco zrekonceptualizować, by w większym stopniu uwzględniała ona dialektyczną rolę między jego wartością wymienną a użyteczną. Chodzi o uchwycenie tego, że niektórzy uczniowie mogą mieć dostęp do kapitału naukowego jako środka do gromadzenia kapitału (np. kwalifikacji, wyników szkolnych) ze względu na jego wartość dla siebie (wartość sama w sobie; wartość wymienna), podczas gdy inni zdają się rozpoznawać wartość nauki i wiedzy naukowej (wartość użyteczna), co prowadzi do różnych form zaangażowania przez nich w naukę (w kontekście tych badań było to zaangażowanie w matematykę). Badacze postulują, by w praktyce edukacyjnej zwrócić większą uwagę na stworzenie możliwości zidentyfikowania wartości w tym, czego się uczniowie uczą, a także tworzenie krytycznej świadomości o możliwości wymiany tej wiedzy w kategoriach kariery zawodowej lub szerszego wkładu w społeczeństwo.

Różny sposób uczestniczenia w nauce był przedmiotem analiz Wonga (2016), który przeprowadził badania eksploracyjne i szczególnie skoncentrował się na kapitale naukowym uczniów z mniejszości etnicznych. Badania obejmowały 46 półustrukturyzowanych wywiadów i 22 godziny obserwacji lekcji z udziałem brytyjskich uczniów w wieku 11-14 lat o zróżnicowanym pochodzeniu etnicznym, np. indyjskim, chińskim, karaibskim, pakistańskim. Na podstawie zgromadzonych danych dotyczących osiągnięć naukowych uczniów, aspiracji i zainteresowań naukowych, kapitału naukowego (który został określony dla każdego ucznia z uwzględnieniem poziomów zaproponowanych przez Archer) badacz wyróżnił pięć rodzajów uczestnictwa w nauce (science). Charakterystyka tych typów jest następująca: uczniowie o negatywnym nastawieniu do nauki (science adverse) nie mają aspiracji do nauki i nie mają zainteresowań z nią związanych, osiągnięć w tej sferze i kapitału naukowego; uczniowie z grupy science intrinsic mają wysokie aspiracje naukowe; zainteresowanie i kapitał, ale niskie osiągnięcia naukowe; uczniowie z grupy science intermediate mają pewne aspiracje, zainteresowania i kapitał naukowy, ale przeciętne osiągnięcia; uczniowie określeni jako science extrinsic osiągają wysokie wyniki w nauce, mają pewien kapitał naukowy, ale 
brakuje im aspiracji naukowych i/lub zainteresowania nauką; uczniowie „wybitni naukowcy” (science prominent) zajmujący się naukami ścisłymi, mają wysokie osiągnięcia naukowe, aspiracje naukowe, wysoki poziom zainteresowania i kapitał naukowy. Wyniki analiz przeprowadzonych przez Wonga (2016) wskazują, że uczniowie pochodzący z mniejszości etnicznych uczestniczą w nauce na różne sposoby. Dlatego też zdaniem tego badacza nie można traktować mniejszości etnicznych jako homogenicznej grupy, co jego zdaniem ma miejsce w dyskursie publicznym, czy nawet naukowym w kontekście kapitału naukowego uczniów czy uczestniczenia w nauce w dorosłym życiu. Co więcej, wyróżnionych typów nie należy odnosić tylko i wyłącznie do uczniów z mniejszości etnicznych, mogą zostać bowiem wykorzystane w odniesieniu do szerszej populacji.

\section{UWAGI KOŃCOWE I WNIOSKI}

Na podstawie wyżej przywołanych ustaleń można skonstatować, że kapitał naukowy jawi się jako zasób pożądany i postrzegany jest jako warunek rozwoju gospodarczego państwa. Z tego też względu staje się przedmiotem coraz liczniejszych analiz teoretycznych i empirycznych. Zaletą tej kategorii jest to, że stwarza możliwość jednoczesnego uchwycenia wielu czynników mających znaczenie dla kształtowania aspiracji naukowych młodych ludzi, a przez to wybór kariery zawodowej. Umożliwia zatem połączenie z jednej strony podejścia całościowego, kompleksowego, z drugiej zaś precyzyjne ujęcie elementów ów kapitał budujących o różnym znaczeniu dla naukowej drogi zawodowej.

Ponadto, jak wynika z powyższego przeglądu badań, kategoria kapitału naukowego jako zmienna edukacyjna jest ciągle dopracowywana i wymaga dalszych eksploracji. Kolejne studia empiryczne odsłaniają słabości czy ograniczenia pierwotnego ujęcia kategorii kapitału naukowego zaproponowanego przez Archer oraz nieuświadomione (nieuwzględnione) wcześniej niuanse i właściwości.

Jednakże nie można postrzegać kapitału naukowego wyłącznie przez pryzmat jego znaczenia dla rozwoju społeczeństwa czy gwarancji rozwoju gospodarczego kraju, bowiem w takiej sytuacji doprowadzić to może, jak określili to Kumar i Singhb (2017), do „psychozy” związanej z rynkiem pracy. Ów kapitał może być i powinien być wykorzystywany przez jednostki do osiągania indywidualnych celów i zmieniania własnej sytuacji życiowej.

Należy także zwrócić uwagę, że zajmowanie się tą kategorią ma znaczenie dla działalności edukacyjnej i jej różnych narzędzi oraz kształtowania polityki edukacyjnej. Rodzina i szkoła stanowią główne przestrzenie budowania kapitału nauko- 
wego. Jeśli szkoły mają być katalizatorem zmiany, powinny zapewniać warunki do rozwoju motywacji uczniów do nauki, wzrostu pewności siebie i świadomości wiedzy oraz kompetencji związanych z dziedzinami STEM. Co więcej, kategoria kapitału naukowego i jej eksploracja w kontekście działań praktycznych stwarza możliwość optymalizacji i integracji działań edukacji formalnej i nieformalnej, bowiem każda z nich może ów kapitał naukowy budować.

\section{Bibliografia}

Archer Ker, L., DeWitt, J., Osborne, J.F., Dillon, J.S., Wong, B., Willis, B. (2013). ASPIRES Report: Young people's science and career aspirations, age 10-14. London, UK: King's College London.

Archer, L., Dawson, E., Dewitt, J., Seakins, A. Wong, B. (2015). „Science capital”: A conceptual, methodological, and empirical argument for extending bourdieusian notions of capital beyond the arts. Journal of Research in Science Teaching, 52(7), s. 922-948, doi10.1002/tea.21227.

Aschbacher P.R., Li, E., Roth, E.J. (2010). Is Science Me? High School Students’ Identities, Participation and Aspirations in Science, Engineering, and Medicine. Journal of Research in Science Teaching, 47(5), s. 564-582.

Black L., Hernandez-Martinez, P. (2016). Re-thinking science capital: the role of 'capital' and 'identity' in mediating students' engagement with mathematically demanding programmes at university. Teaching Mathematics and Its Applications, 35, s. 131-143.

Claussen, S., Osborne, J. (2013). Bourdieu's notion of cultural capital and its implications for the science curriculum. Science Education, 97(1), s. 58-79.

Iłowiecka-Tańska, I. (2016). Budujemy kapitał naukowy. Dyrektor Szkoły, 6(270), s. 78-81.

Jensen, E., Wright, D. (2015). Critical Response to Archer et al. (2015) „Science Capital”: A Conceptual, Methodological and Empirical Argument for Extending Bourdieusian Notions of Capital Beyond the Arts. Science Education, 99(6), s. 1143-1146.

King, H., Nomikou, E. i in. (2015). Teachers' Understanding and Operationalisation of „Science Capital”. International Journal of Science Education, 37(18), s. 2987-3014.

Kumar, R., Singhb, S. (2017). Looking beyond the science capital: conceptualization of „science field” in the context of the Indian society. 3rd International Conference on Theory \& Practice (ICTP, 2017), (s. 70-83). Adelaide, Australia, ISBN: 978-0-9953980-5-4.

Lareau, A., Horvat, E.M. (1999). Moments of social inclusion and exclusion: Race, class, and cultural capital in family-school relationships. Sociology of Education, 72, s. 37-53.

Padwick, A., Dele-Ajayi, O. i in. (2016). Innovative methods for evaluating the science capital of young children. Conference Paper, 2016 IEEE Frontiers in Education Conference (FIE).

Piwowarski, R. (2017). Rola kapitału naukowego w planowaniu i podejmowaniu przez uczniów niektórych kierunków studiów i zawodów. Edukacja Ustawiczna Dorosłych, 1, s. 138-146. 
Smulczyk, M. (2016). Problematyka academic resilience - teoria, badania i praktyczne zastosowanie. Przegląd Badań Edukacyjnych, 23(2), s. 165-194.

„Wystawy dla Wszystkich”. Kapitał naukowy a zwiedzanie centrów nauki przez szkolne grupy szóstoklasistów. Raport podsumowujący, Warszawa 2017. Pobrane z: http://www. kopernik.org.pl/fileadmin/user_upload/PROJEKTY_SPECJALNE/Badacz_w_Koperniku/raporty/Raport_Wystawy_dla_wszystkich_Kapital_Naukowy_2016_Centrum_Nauki_Kopernik.pdf.

Wong, B. (2016). Minority Ethnic Students and Science Participation: a Qualitative Mapping of Achievement, Aspiration, Interest and Capital. Research in Science Education, 46(1), s. $113-127$. 